\title{
Placental fine structure after experimental embryonic death in cows
}

\author{
V. W. Sørensen \\ Department of Anatomy, Royal Veterinary and Agricultural University, Bülowsvej 13, \\ DK-1870 Copenhagen V, Denmark
}

\begin{abstract}
Summary. Early embryonic death was experimentally induced by amnion rupture in pregnant heifers. The subsequent morphological alterations in the placenta were studied with light and electron microscopy, histochemical tests and electron microscope microanalysis. The material from the treated heifers differed from that in untreated cows in the following aspects: the fetal-maternal junction was firm; many endometrial epithelial cells were desquamated and the remaining epithelium showed vacuolization or depletion of organelles; the trophoblast remained at the preattachment stage in its marked phagocytic activity and accumulation of lipid and glycogen, and many of the organelles were degenerated; and the mesenchyme contained extracellular deposits of iron and calcium. It is believed that the changes observed were caused by interruption of the fetal circulation followed by an accumulation of metabolic products.
\end{abstract}

\section{Introduction}

Early embryonic death is a cause of reduced fertility in cattle; Philipsen (1962) reported spontaneous embryonic death in $1 \cdot 3-1.9 \%$ of 18,000 pregnancies. In this material, the fetal membranes continued to grow after the death of the embryo and the conceptus was not expelled until 60-90 days after insemination. The growing membranes of dead embryos tend to mimic normal pregnancy, thus making the diagnosis of early pregnancy uncertain.

Although comprehensive investigations with the light microscope (Björkman, 1954; Moss, Sykes \& Wrenn, 1956; Greenstein, Murray \& Foley, 1958) and the electron microscope (Björkman \& Bloom, 1957; Björkman, 1968a, b, 1969, 1973; Leiser, 1972, 1975) have been reported of the normal bovine placenta, only preliminary studies have been made of placental morphology after embryonic death (Sørensen, 1973; Philipsen \& Sørensen, 1972). The aim of this investigation was to elucidate the morphological alterations of the cells involved in the fetal-maternal association, caused by embryonic death. Since, for obvious reasons, spontaneous cases could not be used in this study embryonic death was induced experimentally.

\section{Materials and Methods}

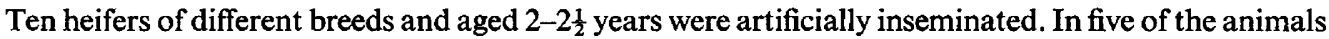
the embryos were killed 35-42 days after insemination by rupturing the amnion by squeezing per rectum (Table 1). This method was successfully employed in eliminating one of the embryos in twin pregnancies (Philipsen, 1962), and was therefore considered valid for our purpose. The animals were slaughtered 60-62 days after insemination. The five untreated heifers were killed when 40-61 days pregnant (Table 1). Between 7 and $20 \mathrm{~min}$ after slaughter the uteri were opened for removal of placental tissue.

Tissue blocks $\left(1 \mathrm{~mm}^{3}\right)$ from treated and untreated heifers were taken from 3-5 different cotyledons, caruncles, placentomes and from areas between them. The samples were fixed at $4{ }^{\circ} \mathrm{C}$ in $2.5 \%$ glutaraldehyde in $0.1 \mathrm{M}$-phosphate or cacodylate buffer at $\mathrm{pH} 7 \cdot 4$ (see Table 1) for 1-2 hr and post-fixed in $1 \%$ osmium tetroxide in the same buffer. After dehydration in a graded series of ethanol the tissue 
Table 1. Details of the treatment of heifers in the present study and some of the differences between them

\begin{tabular}{|c|c|c|c|c|c|c|}
\hline Heifer (breed) & Treatment & $\begin{array}{l}\text { Rupture of } \\
\text { amnion after } \\
\text { insemination } \\
\text { (days) }\end{array}$ & $\begin{array}{l}\text { Sampling } \\
\text { after } \\
\text { insemination } \\
\text { (days) }\end{array}$ & $\begin{array}{l}\text { Buffer for } \\
\text { fixation }\end{array}$ & $\begin{array}{l}\text { Contact between } \\
\text { maternal } \\
\text { epithelium and } \\
\text { trophoblast* }\end{array}$ & $\begin{array}{l}\text { Inclusions in the } \\
\text { mesenchyme } \\
\text { containing iron } \\
\text { and calcium }\end{array}$ \\
\hline 1 (RDM) & + & 35 & 61 & Phosphate & + & $\cdots$ \\
\hline 2 (DRK) & + & 42 & 60 & Phosphate & - & + \\
\hline 3 (RDM) & + & 39 & 62 & Cacodylate & + & + \\
\hline $\begin{array}{c}4(\mathrm{RDM} \times \\
\text { SDM })\end{array}$ & + & 40 & 61 & Cacodylate & - & + \\
\hline 5 (RDM) & + & 40 & 60 & Cacodylate & + & + \\
\hline $\begin{array}{c}6(\mathrm{RDM} \times \\
\mathrm{SDM})\end{array}$ & - & - & 40 & Cacodylate & + & - \\
\hline 7 (RDM) & - & $一$ & 61 & Cacodylate & + & - \\
\hline 8 (RDM) & - & - & 60 & Cacodylate & + & - \\
\hline 9 (RDM) & - & 一 & 60 & Cacodylate & + & - \\
\hline $10(\mathrm{RDM})$ & - & - & 49 & Cacodylate & + & - \\
\hline
\end{tabular}

* In Heifers 1, 3, 5, and 6 there was some reduction in the number of layers.

RDM = Red Danish milk-breeding; SDM = Danish Friesian; DRK = Danish short-horned.

was embedded in Epon (Luft, 1961 ; Spurr, 1969). Thick sections, 1-2 $\mu \mathrm{m}$, were stained with toluidine blue. Thin sections, $50-80 \mathrm{~nm}$, on uncoated grids were stained with uranyl acetate and lead citrate before examination in a Siemens Elmiskop 101. Unstained or stained sections 150-200 nm thick were examined by X-ray microanalysis in the EMMA 4 analytic microscope (A.E.I. Scientific Apparatus Ltd, Manchester, England). Electron micrograph negatives were analysed in a measuring bench for Fourier transformation of two-dimensional image signals and spatial frequency filtering (LFO: Spindler and Hoyer, KG, Göttingen). Tissue from the same placentomes or cotyledons and caruncles were fixed in Bouin's fluid, embedded in paraffin wax, sectioned and stained with haemalum and eosin. Staining was carried out with periodic acid-Schiff (PAS) with and without diastase digestion to demonstrate glycogen and mucopolysaccharides, Perls' Prussian blue for $\mathrm{Fe}^{+++}$and v. Kossa for calcium (Barka \& Anderson, 1963).

\section{Results}

The association between the maternal epithelium and the trophoblast was very loose and was only found in Heifers 1, 3 and 5 in a few blocks. Therefore the fetal and the maternal sides of the placenta will be described separately for comparison with material from the untreated heifers. The structure of the placenta from untreated heifers is shown diagrammatically in Text-fig. 1.

\section{The maternal epithelium}

The maternal epithelium was desquamated over large areas and the remaining cells showed wide variations from nearly normal (Pl. 1, Fig. 3) to vacuolated degenerative forms (Pl. 1, Fig. 2).

Caruncles. On the caruncles with remnants of crypts the few remaining epithelial cells were almost similar to those in the untreated material, but the cells were lighter and contained fewer mitochondria and less endoplasmic reticulum (Pl. 2, Figs 5 and 6). The epithelium was lower and the nuclei showed more condensation of chromatin at the nuclear periphery than in the untreated heifers. Furthermore, the plasma membrane was often damaged in the depth of the crypts.

The intercaruncular epithelium. The remaining epithelium in the intercaruncular area varied from low cuboidal to high columnar with wide variations in colour intensity after staining with toluidine blue, especially in the more degenerated areas. The vacuolization in the apical part of the cells was more pronounced than in the untreated material (PI. 1, Figs 1, 2, 3 and 4). Intercellular spaces (Pl. 1, Fig. 4, inset) with a flocculent or electron-dense content should be compared with the 


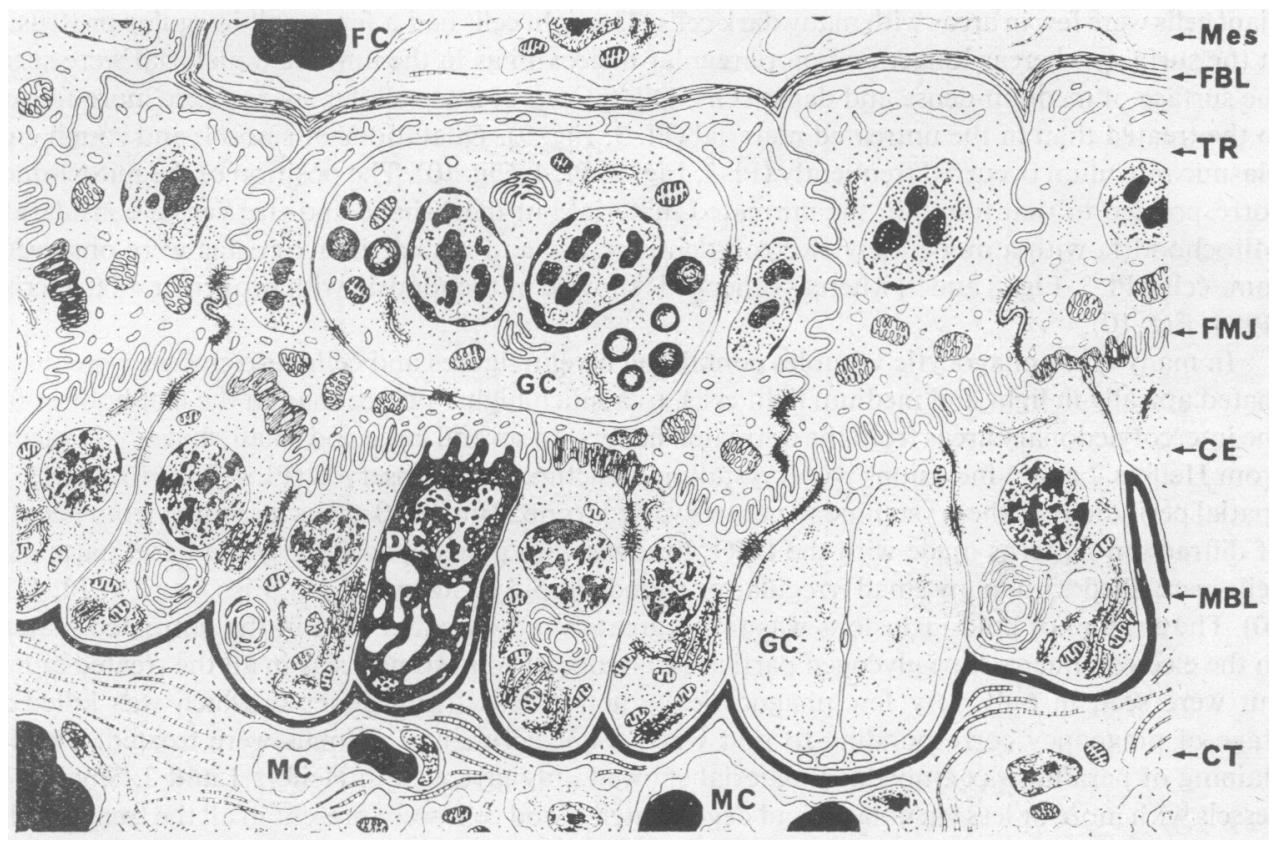

Text-fig. 1. Schematic drawing of the fine structure of the normal bovine placentome. The cryptal epithelium (CE) rests on a basal lamina (MBL) under which a layer of connective tissue (CT) rich in capillaries (MC) is found. At the fetal-maternal junction (FMJ) microvilli from the trophoblast and cryptal epithelium interdigitate in a complex manner; the fetal-maternal space is filled with electron-dense material in some areas. The trophoblast (TR) is separated from the mesenchymal core (Mes) containing fetal capillaries (FC) by a well defined basal lamina (FBL). In the cryptal epithelium, a degenerated cell (DC) is shown. Giant cells $(\mathrm{GC})$ with two nuclei are indicated in the maternal and the fetal epithelium.

appearance of the epithelium as seen in PI. 1, Fig. 3, where the spaces between the cells nearly reached the basal lamina. The cells often contained two nuclei (Pl. 1, Figs 2 and 3 ) but cells with up to 5 nuclei were also observed. In the untreated material epithelial cells with two nuclei were observed near the openings of uterine glands and there were more of them than in the intercaruncular and caruncular epithelium where they appeared more like giant cells. In the treated material the nuclei were more tortuous and often showed chromatin condensation at the periphery. The rough and smooth endoplasmic reticulum was diminished compared to the untreated material, whereas free ribosomes were abundant.

The mitochondria were numerous and varied in size and shape as in the untreated material (Pl. 1, Fig. 4). All transitional forms from mitochondria of normal appearance with straight cristae and an even outer membrane through light mitochondria with many more or less damaged cristae to vacuolized mitochondria were seen (Sørensen, 1973). In Heifers 2 and 4 many small or large clusters of glycogen granules were seen in the cells. Glycogen was also observed in the maternal epithelium from the untreated heifers, but it was only associated with the openings of the uterine glands. Dense bodies were more frequently seen than in the untreated material, both as round bodies of $1 \mu \mathrm{m}$ and as elongated irregular bodies with a length of approximately $300 \mathrm{~nm}$ and a width of $70 \mathrm{~nm}$ or slightly more (P1. 1, Fig. 4).

\section{The trophoblast}

The trophoblast was usually intact ( $\mathrm{Pl}$. 3, Figs 7 and 8), but many areas showed light, often swollen and damaged, cells or desquamated epithelium. In other areas light cells, medium-dense cells and dark degenerating cells were mingled to a much higher degree than in the untreated material, The 
giant cells were few in areas with many dark cells. The light cells had a few small irregular protrusions at the surface, whereas longer and more regular microvilli as in the untreated material were seen at the surface of medium-dense and dense cells. Dilatations of intercellular spaces were more frequent in the treated than in the untreated material (Pl. 3, Fig. 9). Dilatations of smooth and rough endoplasmic reticulum occurred frequently (PI. 3, Fig. 9; Pl. 4, Fig. 10). The position of the mitochondria corresponded to that found in the untreated material but their shape and size varied considerably. Mitochondria with a moderately electron-dense matrix and regular intact cristae were observed in some cells (P1. 3, Figs 8 and 9) whereas other cells showed mitochondria with broken or dilated cristae (Pl. 4, Fig. 10).

In many areas phagocytic vacuoles containing myelin figures and cellular elements were disseminated apically in light and medium light cells, to a much higher degree than in the trophoblast from the intercotyledonary areas from the untreated heifers. In several large and small phagocytic vacuoles from Heifers 2 and 5 inclusions with crystalline structures were observed (Pl. 4, Fig. 10, inset). The spatial periodicity in the crystalline structures varied from $20 \mathrm{~nm}$ to $10 \mathrm{~nm}$ as measured from negatives of diffraction patterns made with the LFO. In areas with phagocytic activity the basal parts of the cells were filled with many small irregular or rounded lipid inclusions (PI. 3, Figs 8 and 9; Pl. 4, Fig. 10). The amount of lipid inclusions was much greater in the treated than in the untreated material. In the electron microscope glycogen particles were observed in some areas in all the treated animals but were seen in only very few phagocytically active cells from Heifer 6, which was killed at a stage of pregnancy corresponding to that when the experimental animals were treated. The PAS staining of paraffin wax-embedded material showed only glycogen in Heifers 1 and 2. Small blood vessels with more or less vacuolated and degenerated blood cells were present in all the treated heifers except for No. 1. Characteristic extracellular deposits in the mesenchyme were observed in all the treated heifers (Pl. 3, Figs 7 and 8) except for Heifer 1, but not in the untreated heifers. Electron microscope microanalysis (EMMA) showed that iron and calcium were components of the deposits (Table 2 and Pl. 4, Fig. 11). These deposits sometimes showed differences in electron density as seen in Pl. 3, Fig. 8 (inset) or appeared as concentric electron-dense rings. Histochemical tests of the inclusions showed that they contained iron but not calcium.

Electron microscope microanalysis of the electron-dense areas in the phagocytic vacuoles near crystalline inclusions gave a positive reaction for iron, whereas no calcium was detected. The crystalline inclusions did not contain measurable quantities of iron.

\section{EXPLANATION OF PLATE 1}

Fig. 1. Light micrograph of normal maternal epithelium (ME) from the intercaruncular region near the opening of a uterine gland (Heifer 9). A border of microvilli (Mv) is seen at the surface. Many cells contain two closely related nuclei $(\mathrm{N})$. Vacuoles are seen apically in the cells. The numerous small granules represent mitochondria. Maternal capillaries with erythrocytes are seen in the connective tissue (CT). Toluidine blue.

Fig. 2. Light micrograph of maternal epithelium of Heifer 1 after induced embryonic death. The area corresponds to that illustrated in Fig. 1. The cells show wide variations in staining intensity and most of them contain many apically placed vacuoles. Double nuclei $(N)$ are common and the cells contain many mitochondria. The surface is lined with a fine border of microvilli (Mv). Wavy, somewhat blurred basal lamina. Toluidine blue.

Fig. 3. Light micrograph of intercaruncular maternal epithelium of Heifer 1 showing only small contact areas between some of the cells (arrows). The epithelium contains some dark cells. Binucleated cells are common. Several small vacuoles and many mitochondria can be observed in the cytoplasm. Toluidine blue.

Fig. 4. Electron micrograph of apical part of intercaruncular epithelium with microvilli (Mv) illustrated in Pl. 1. Fig. 2 (Heifer 1). The intercellular space (IC) is sealed by a junctional complex (JC). Many large mitochondria (M) with straight cristae are seen apically among small irregular dense inclusions (Di), and vacuoles (V) of different size. The endoplasmic reticulum (ER) is dilated. In some cells numerous vesicles (Ve) can be seen below the terminal web (Tw). The small dense granules in the cytoplasm are glycogen. Inset: Heifer 2, part of an intra-epithelial canaliculus lined with microvilli (compare with Fig. 3) and containing an electron-dense material. 
PLATE
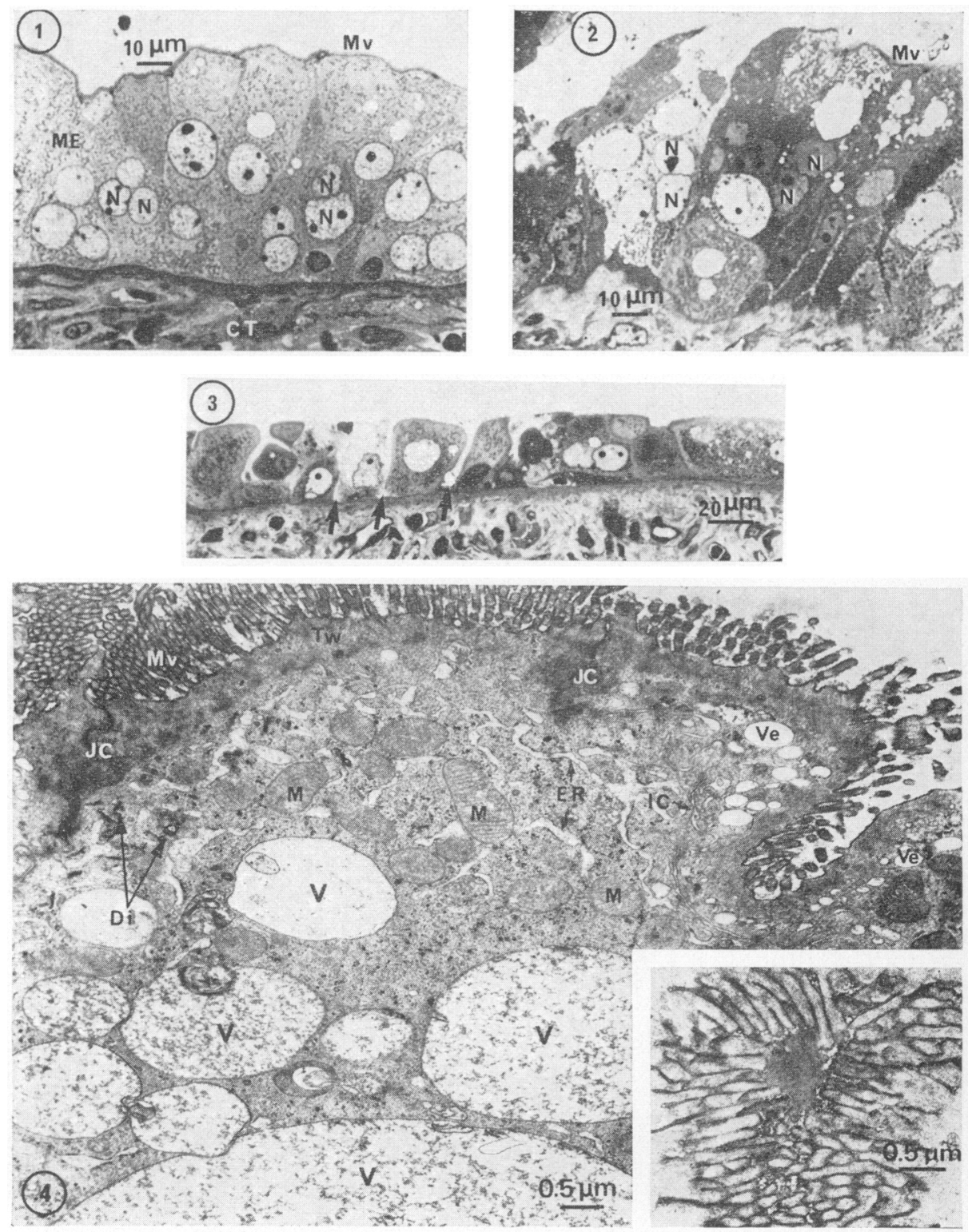


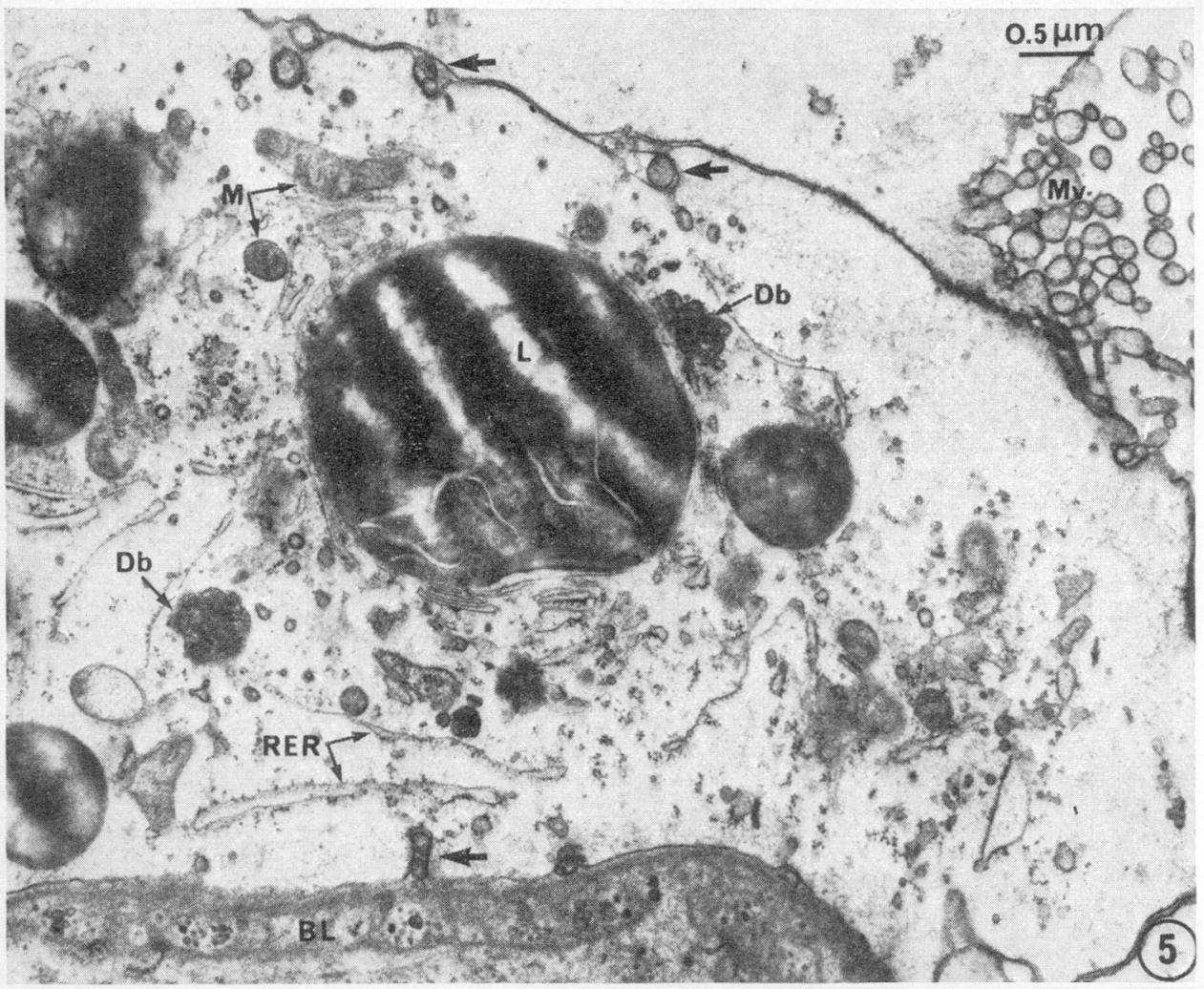

$0.2 \mu \mathrm{m}$

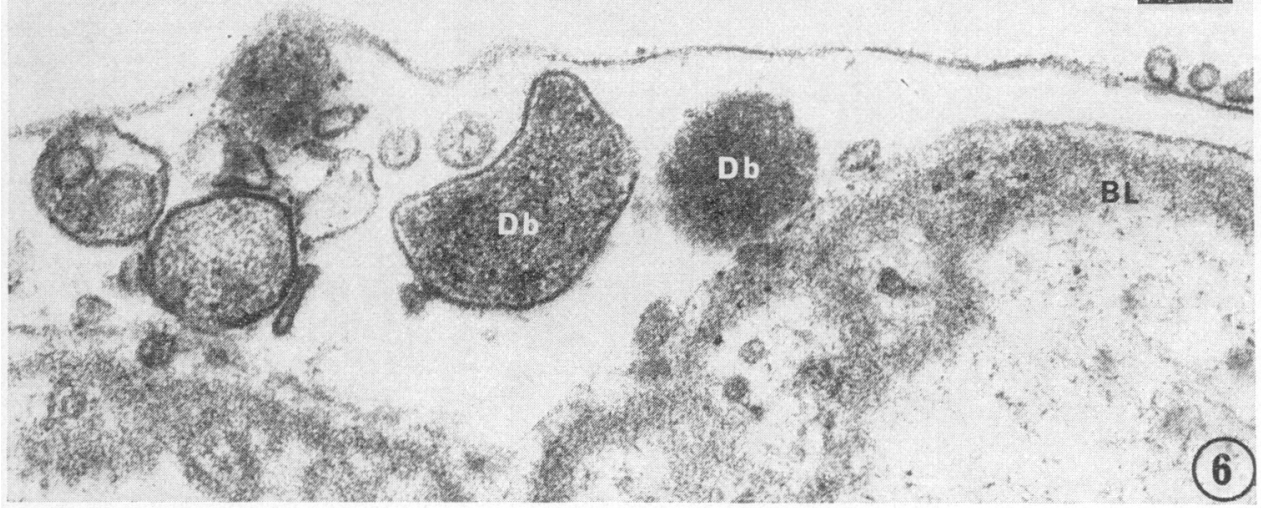

Fig. 5. Electron micrograph of cryptal epithelium of Heifer 5 showing ir regular microvilli (Mv) at the surface and some membrane-bounded structures in the intercellular spaces (arrows). The large lipid inclusion (L) is surrounded by whorls of smooth endoplasmic reticulum. Profiles of rough (RER) and smooth endoplasmic reticuium are sparse and only a few small mitochondria $(\mathrm{M})$ are seen. Some dense bodies (Db) can be seen near the lipid inclusion. The epithelium is separated from the connective tissue by a basal lamina (BL).

Fig. 6. Electron micrograph from Heifer 5 showing part of very low cryptal epithelial cell with dense bodies (Db) resting on a maternal basal lamina (BL), irregular and somewhat thickened, but typical for the treated cases. 
PLATE 3


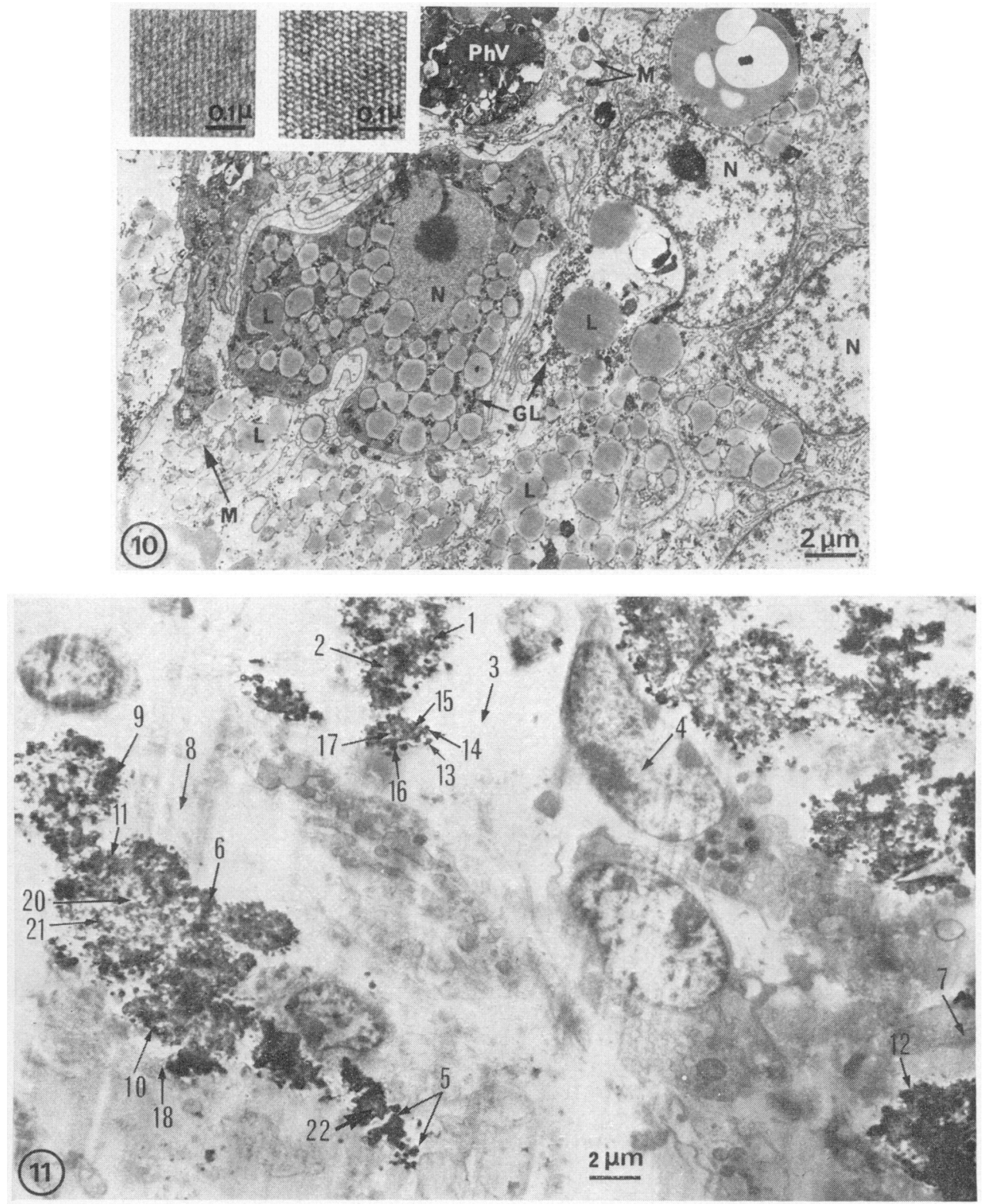

Fig. 10. Electron micrograph of trophoblast of Heifer 2 showing wide variation in electron density of cytoplasm and nuclei $(N)$. The cells are heavily loaded with lipid droplets ( $L$ ) and the electron-dense aggregation of granules between them represent glycogen (GL). Mitochondria (M) can be seen at all cellular levels while dilatations of the endoplasmic reticulum with vacuolization are most abundant in the light cells. A large phagocytic vacuole ( $\mathrm{PhV}$ ) containing lattice structures (see inset) is situated near the surface. Insets: Two different sections of lattice structures from Heifers 2 and 5.

Fig. 11. Electron micrograph of unstained, approximately $150-200 \mathrm{~nm}$, sections of inclusions in the mesenchyme of Heifer 3 for electron microscope microanalysis. The numbered areas correspond to those indicated in Table 2 . 


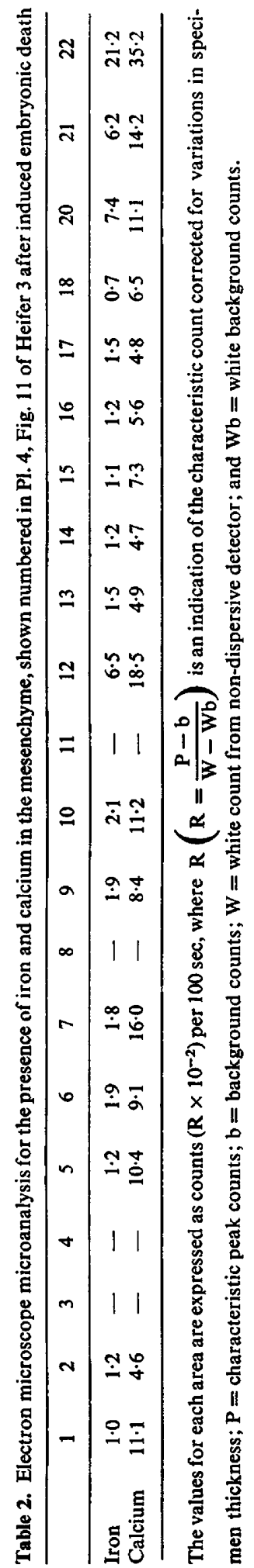




\section{Discussion}

Spontaneous early embryonic death may be caused by various factors and can occur at different stages of pregnancy and hence of embryonic development. The method of rupturing the amnion kills the embryo (Philipsen, 1962), but the subsequent morphological alterations in the placenta do not necessarily conform to those following other causes of embryonic death. However, an immediate consequence of embryonic death of whatever cause will be interruption of the fetal circulation. This is mainly supplied by the umbilical arteries and veins whereas the vitelline circulation plays a subordinate if any role at the developmental stages in question. Many of the changes described above can be explained as consequences of the interrupted circulation, e.g. degenerative alterations and accumulation of metabolites. The surface epithelium from the experimental uteri showed many similarities to the control material in some small areas, and the degenerative changes could be caused by the absence of stimulation from a viable embryo. Correspondingly, the remaining cryptal epithelium was often highly altered and contained very few organelles.

A constant feature in the trophoblast from the treated heifers was the presence of glycogen. Glycogen was also present in the trophoblast from an early untreated heifer but only in cells from the intercotyledonary areas with high phagocytic activity. This is in accordance with light microscopic observations of very small amounts of glycogen in the trophoblast (Björkman, 1954, 1956; Greenstein et al., 1958). The bovine columnar trophoblast contains ketose reductase, which converts fructose to sorbitol, which in turn is converted to glucose by aldose reductase (Rama, Castellano, Germino, Mucucci \& Ohanian, 1973). Therefore, the impeded fetal utilization of trophoblastic metabolic products may result in storage of glycogen in the columnar trophoblast. Furthermore, small amounts of glycogen secreted by the uterine glands (Yamauchi, Kakishita \& Kotera, 1969; Kojima \& Selander, 1970) will be accumulated after phagocytosis.

The trophoblast from the experimental animals was reminiscent of normal trophoblast from the preattachment stage in the characteristic basal accumulation of lipid in the cells, but the accumulations of lipid were more pronounced in the experimental material.

Lattice structures were observed in connection with cell fragments in phagocytic vacuoles in the trophoblast from the experimental material (PI. 4, Fig. 10). Similar crystalline inclusions have been seen in related tissue from rabbit and rat blastocysts (Enders \& Schlafke, 1969; Tachi, Tachi \& Lindner, 1970) and in trophoblast from a preimplantation sheep blastocyst (Wintenberger-Torrés \& Fléchon, 1974). Lattice structures were not observed in the control material, but here the trophoblast was collected in relatively later stages of pregnancy than in the studies mentioned above.

Characteristic of the experimental material were the extracellular deposits containing iron and calcium. In the human placenta, the accumulation of iron has been observed in the villous stroma in the second trimester (McKay, Hertig, Adams \& Richardson, 1958). In crab-eater seals, Sinha \& Erickson (1974) described intra- and extracellular granular bodies containing iron in the mesenchyme,

\section{EXPLANATION OF PLATE 3}

Fig. 7. Light micrograph of chorionic villi with trophoblast of Heifer 3. At lower left there are many phagocytic vacuoles and the light basal part is filled with lipid inclusions (L). Giant cells (GC) are also numerous. Capillaries (FC) and many dark extracellular deposits can be seen in the mesenchyme (Mes). Toluidine blue.

Fig. 8. Slightly oblique electron micrograph section of well preserved trophoblast from Heifer 4. There is an apical irregular border of microvilli (Mv). The nuclei $(\mathrm{N})$ are situated in the middle part of the cells, while accumulations of smooth endoplasmic reticulum (SER) can be seen at different levels. Mitochondria (M) of various contours are mainly present in the apical parts of the cells, where most of the phagocytic vacuoles $(\mathrm{PhV})$ are also situated. The small dense granules between the lipid inclusions $(\mathrm{L})$ represent glycogen granules. The trophoblast is separated from the mesenchyme (Mes) by a well defined basal lamina (BL). The inclusions (In) in the mesenchyme contain iron and calcium (see PI. 4, Fig. 11 and Table 2). Inset: Heifer 3, higher magnification of extracellular mesenchymal deposits corresponding to (In).

Fig. 9. Electron micrograph of basal part of trophoblast of Heifer 1 resting on a basal lamina (BL). The intercellular space (IC) is widened and the lateral cell surfaces are enlarged by protrusions (CP). The mitochondria (M) have straight or branched, slightly dilated cristae in a moderately electron-dense matrix. Profiles of rough endoplasmic reticulum (RER), smooth endoplasmic reticulum (SER), glycogen granules (GL) and lipid inclusions (L) are seen. 
which closely resembled the extracellular mesenchymal inclusions in the present treated heifers. The accumulation of iron and calcium may be a result of phagocytic activity of trophoblast, since iron is either a secretory product from the uterine glands phagocytosed by the trophoblast or comes from phagocytosed maternal erythrocytes (Wynn, 1967; Yamauchi, Kotera \& Kakishita, 1971). These activities of histotrophic absorption obviously lead to the accumulation of iron as the fetal blood supply is cut off.

I gratefully acknowledge the help of Dr H. Philipsen for procuring the material and giving clinical assistance. A.E.I. Scientific Apparatus Ltd generously undertook the electron microscope microanalysis through Thorleif Lavold's agency and the technical assistance of Dawn Chescoe. Dr R. Lessing, Spindler \& Hoyer, made the diffraction analysis of the crystalline structures with the LFO.

\section{References}

BARKA, T. \& ANderson, P.J. (1963) Histochemistry, Theory, Practise and Bibliography. Hoeber Medical Division, New York.

BJöRKMAN, N. (1954) Morphological and histochemical studies on the bovine placenta. Acta anat. 22, Suppl. 22, pp. 1-92.

BuöRKMAN, N. (1956) Morphological studies on the epithelia of the intercotyledonary component of the bovine placenta. Acta morph. neerl.-scand. 1, 1-10.

BJörKMAN, N. (1968a) Specialization of endoplasmic reticulum in bovine placental cells. Z. Zellforsch. mikrosk. Anat. 90, 535-541.

BJörkMAN, N. (1968b) Fine structure of cryptal and trophoblastic giant cells in the bovine placentome. J. Ultrastruct. Res. 24, 249-258.

BJöRKMAN, N. (1969) Light and electron microscopic studies on cellular alterations in the normal bovine placentome. Anat. Rec. 163, 17-30.

BJöRkMAN, N. (1973) Fine structure of the fetal-maternal area of exchange in the epithelio-chorial and endothelio-chorial types of placentation. Acta anat. 86, Suppl. 61, 1-22.

BJöRKMAN, N. \& BLOOM, G. (1957) On the fine structure of the foetal-maternal junction in the bovine placentome. Z. Zellforsch. mikrosk. Anat. 45, 649-659.

ENDERS, A.C. \& SCHLAFKe, S. (1969) Cytological aspects of trophoblast-uterine interaction in early implantation. Am. J. Anat. 125, 1-30.

Greenstein, J.S., Murray, R.W. \& Foley, R.C. (1958) Observations on the morphogenesis and histochemistry of the bovine preattachment placenta between 16 and 33 days of gestation. Anat. Rec. 132, 321-335.

KoJima, Y. \& Selander, U. (1970) Cyclical changes in the fine structure of bovine endometrial gland cells. Z. Zellforsch. mikrosk. Anat. 104, 69-86.

LEISER, R. (1972) Licht- und Elektronenmikroskopische Untersuchungen der Prëimplantation beim Rind. Proc. 8th Congr. Eur. Ass. Vet. Anat., Vienna, p. 48.

Leiser, R. (1975) Kontaktaufnahme zwischen Trophoblast und Uterusepithel während der frühen Implantation beim Rind. Anat. Histol. Embryol. 4. 63-68.

LuFT, J.H. (1961) Improvements in epoxy resin embedding methods. J. biophys. biochem. Cytol. 9, 409-414.

MCKay, D.G., Hertig, A.T., Adams, E. \& Richardson,
M. (1958) Histochemical observations on the human placenta. J. Obstet. Gynec. 12, 1-36.

Moss, S., SYKes, I.F. \& WRENN, T.R. (1956) Some observations on the bovine corpus luteum and endometrium during early stages of pregnancy. $A m . J$. vet. Res. 17, 607-614.

Philipsen, H. (1962) Kliniske iagtagelser af tidlig fosterdad hos kvæget. Proc. 9th Nordic Vet. Congr., Copenhagen pp. 539-545. Ed. E. Blom.

Philipsen, H. \& Sørensen, V.W. (1972) Den bovine placentas finstruktur efter eksperimentelt fremkaldt fosterdød. In Annual Report Sterility Research Institute, The Royal Veterinary and Agricultura University, pp. 147-159.

Rama, F., Castellano, M.A., Germino, N.I., Mucucci, M. \& Ohanian, C. (1973) Histochemical location of ketose-reductase in the placenta and fetal tissues. J. Anat. 114, 109-113.

Sinha, A.A. \& Erickson, A.W. (1974) Ultrastructure of the placenta of Antarctic seals during the first third of pregnancy. Am. J. Anat. 141, 263-280.

SøreNSEN, V.W. (1973) Ultrastructural observations on the bovine placenta at early embryonic death. Proc. 7th Int. Symp. Zootech., Milan, p. 537.

SPURR, A. R. (1969) A low-viscosity epoxy resin embedding medium for electron microscopy. $J$. Ultrastruct. Res. 26, 31-43.

TACHI, S., TACHI, C. \& LiNDNER, H.R. (1970) Ultrastructural features of blastocyst attachment and trophoblastic invasion in the rat. J. Reprod. Fert. 21, 37-56.

Wintenberger-Torrés, S. \& Fléchon, J.-E. (1974) Ultrastructural evolution of the trophoblast cells of the pre-implantation sheep blastocyst from day 8 to day 18. J. Anat. 118, 143-153.

WYNN, R. (Ed.) (1967) In Discussion, Fetal Homeostasis, Vol. 2, pp. 46-51. Academic Press, New York.

Yamauchi, S., Kakishita, T. \& Kotera, K. (1969) Histological study of the pregnant uterus in the cow. III. Study on lipids, glycogen and carbohydrates in the endometrium (intercaruncular region). Jap. J. zootech. Sci. 40, 520-536.

Yamauchi, S., Kotera, K. \& Kakishita, T. (1971) Histological study of the pregnant uterus in the cow. IV. Study on iron and calcium in the placenta. Jap. J. zootech. Sci. 42, 344-357. 